\title{
CCL21 wt Allele
}

National Cancer Institute

\section{Source}

National Cancer Institute. CCL21 wt Allele. NCI Thesaurus. Code C49738.

Human CCL21 wild-type allele is located within 9p13 and is approximately $1 \mathrm{~kb}$ in length. This allele, which encodes C-C motif chemokine 21 protein, plays a role in mediating the homing of lymphocytes to secondary lymphoid organs. 